\title{
The Analysis of Critical Thinking Trends in Primary School Teacher Candidates
}

\author{
Baiq Niswatul Khair \\ Primary School Education Program \\ Universitas Mataram \\ Mataram, Indonesia \\ Hasnawati Hasnawati* \\ Primary School Education Program \\ Universitas Mataram \\ Mataram, Indonesia \\ hasnawati@unram.ac.id
}

\author{
Itsna Oktavianti \\ Primary School Education Program \\ Universitas Mataram \\ Mataram, Indonesia \\ A. Wahab Jufri \\ Biology Education Program \\ Universitas Mataram \\ Mataram, Indonesia
}

\begin{abstract}
This study aims to determine the level of critical thinking tendencies (CTT) for primary school teacher candidates. This research is a descriptive study with a total of 118 research subjects at Primary School Education Program at the faculty of teacher training and education Universitas Mataram which were randomly selected. CTT data were collected through a modified CCT instrument consisting of seven indicators, namely the inquisitiveness, the openmindedness, the system, the analysis, the truth-seeking, selfconfidence, and the maturity of judgment. Data were analyzed descriptively and the results showed that the average score of CCT level of the student was in the positive category. Furthermore, based on each indicator, it is found that from the seven indicators, the maturity of judgment indicator is at the ambivalent level, while the other indicators are in the positive category. Thus, it can be concluded that the level of critical thinking tendencies of prospective primary school teacher candidates is in the positive category.
\end{abstract}

Keywords - critical thinking tendencies, prospective primary school teachers

\section{INTRODUCTION}

On one hand, teacher quality is an important factor in determining student achievement in learning. On the other hand, to improve teacher quality, it is very important to understand what influences the level of teacher professionalism. In recent years, efforts to improve teacher quality have become a challenge among several countries, including Indonesia. In addition to increasing teaching staff, some countries experience high levels of friction among new teachers and a lack of qualified teachers in certain fields of study [1]

The task of teachers in the 4.0 revolution era is not only to embed conceptual knowledge based on content, but more complex. The teachers must be equipped with information communication related to knowledge and skills relevant to the demands of the times, emotional, moral, and spiritual maturity. In addition, the teachers in the $21^{\text {st }}$ century are required to have special expertise, competence and high dedication in carrying out their professional duties. One of the $21^{\text {st }}$ century skills that must be possessed by teachers is the ability to think critically [2] [3].

Teachers need to have the ability to think critically before training their students to think critically. Critical thinking is a demonstration of thought that classifies, analyzes and evaluates interests [4]. Critical thinking is thinking that is reasonable and reflective, thinking is focused on deciding what to believe or do. [5] Next, critical thinking is an approach to the current problems, questions, and issues [6].

Critical thinking has two main dimensions, namely cognitive skills and the tendency to think critically [5] [7]. The tendency to critical thinking is an attitude towards critical thinking [8]. Cognitive thinking skills are the intellectual aspects of critical thinking, whereas the tendency to critical thinking is the tendency of one's critical thinking about something or one's perspective on the problem at hand. Both components affect each other [9].

The critical thinking skills have 6 indicators: first interpretation - the ability to understand and express the meaning or significance of a wide variety of experiences. Second analysis - the ability to identify the relationship of several things. Third evaluation - the ability to test the truth of a statement. Fourth inference - namely the ability to identify and choose the elements needed to draw up a logical conclusion. Fifth explanation - the ability to state the results of thought, explain the reasons based on consideration and evidence. And sixth self-regulation one's awareness to monitor cognitive activities themselves [7].

Meanwhile the critical thinking tendency (CTT) is interpreted as a critical spirit or a tendency to think critically that has the characteristics of deep curiosity, sharpness of thought, perseverance in developing reason and the need for reliable information [5]. The tendency to critical thinking is defined as a tendency towards attitude 
in taking an action when facing problems in certain conditions [10].

The tendency to critical thinking is a tendency towards a pattern of intellectual behavior. Critical thinking tendencies are grouped into seven indicators, namely: first the search for truth (habits always want the best understanding of a particular situation, accompanied by reasons and associated evidence), second open thinking (tendency to let others voice their views), third analysis (tendency to be careful of what happens next), fourth systematic (tendency or hard work habits to solve problems with discipline and orderly), fifth self-confidence (tendency to trust the use of reason and reflective thinking to solve problems), sixth curiosity (tendency to be curious everything, even though it is clearly useless at this time), and the seven maturities in making decisions [9].

The purpose of this study is to determine the level of critical thinking tendencies (CTT) for primary school teacher candidates.

\section{RESEARCH METHOD}

The study was a descriptive study with a survey methodology, in which sample groups were randomly selected. The research subjects were 118 students of primary teacher education program who were chosen randomly.

Data on critical thinking tendencies were obtained through a critical thinking tendency questionnaire. The questionnaire contained 75 statements representing 7 indicators of critical thinking tendency according to Facione (2009) namely curiosity (the inquisitiveness), open thinking (the open-mindedness), systematic (the systematicality), analysis (the analyticality), truth seeking (the truth-seeking), self-confidence, and the maturity of judgment.

Each indicator has a range of scores with 10 as a minimum score and 60 as a maximum score, so the total score for the seven indicators is 70 for a minimum score and 420 for a maximum score. The scores obtained was used to indicate the level of critical thinking tendencies possessed by the students and to serve as the basis for grouping the students into several groups according the level of critical thinking tendencies with the criteria as in Table 3.1

TABLE I. CRITERIA OF CTT

\begin{tabular}{|c|c|c|}
\hline Each Indikator & Total Score & Characteristics of CTT \\
\hline$\geq 50$ & $\geq 349$ & Straight \\
\hline $40-49$ & $280-348$ & Positif \\
\hline $31-39$ & $211-279$ & Ambivalent \\
\hline$\leq 30$ & $\leq 210$ & Negative \\
\hline
\end{tabular}

\section{RESULTS AND DISCUSSION}

Data on the results of the critical thinking tendency of prospective primary school teacher students in general showed an average score of 321.68 with a standard deviation of 16.82. This indicates that the characteristics of students' critical thinking tendencies are in the positive category. Whereas if seen based on indicators, the highest score is found in the open mindedness indicator, while the lowest score obtained by the indicator of maturity of judgment shows that the prospective teachers of primary school education program at Universitas Mataram have an average ability in critical thinking and this is good enough even though this still need to be improved.

Likewise, with the 5 other indicators, the average score obtained (as shown in table 1) gives a picture that the average student candidates for primary school teachers have a pretty good ability to enter the positive category. This is in line with the research results of Ordem and Yildirim \& Ozkarahman [12] [13].

TABLE II. STUDENT CRITICAL THINKING TENDENCY SCORE IN PRIMARY TEACHERS

\begin{tabular}{|c|c|c|}
\hline Indicator & Mean Scores \pm SD & Category \\
\hline Truth-seeking & $48.47 \pm 3.96$ & Positive \\
\hline Open-mindedness & $49.28 \pm 4.05$ & Positive \\
\hline Analyticity & $48 \pm 3.42$ & Positive \\
\hline Systematicity & $45.41 \pm 4.51$ & Positive \\
\hline Self confident & $46.52 \pm 4.56$ & Positive \\
\hline Inquisitiveness & $43.6 \pm 4.02$ & Positive \\
\hline Maturity of Judgement & $38.78 \pm 4.42$ & Ambivalent \\
\hline Overall CTD & $\mathbf{3 2 1 . 6 8} \pm 16.82$ & Positive \\
\hline
\end{tabular}

The level of students' critical thinking tendencies shows better results along with increased learning time [14]. Prospective primary school teacher students have gained a lot of knowledge both from the faculty and from previous education, thereby increasing the students' curiosity and critical thinking tendencies. Learning obtained by someone at the university level will increase his/her ability to think critically. Students are included in the age of maturity so that the tendency of students to think critically is also higher than that of students at lower levels [15].

The detail percentage of the level of critical thinking tendency of prospective primary school teacher candidates who were sampled in this study are described in the following 4.1 graph 


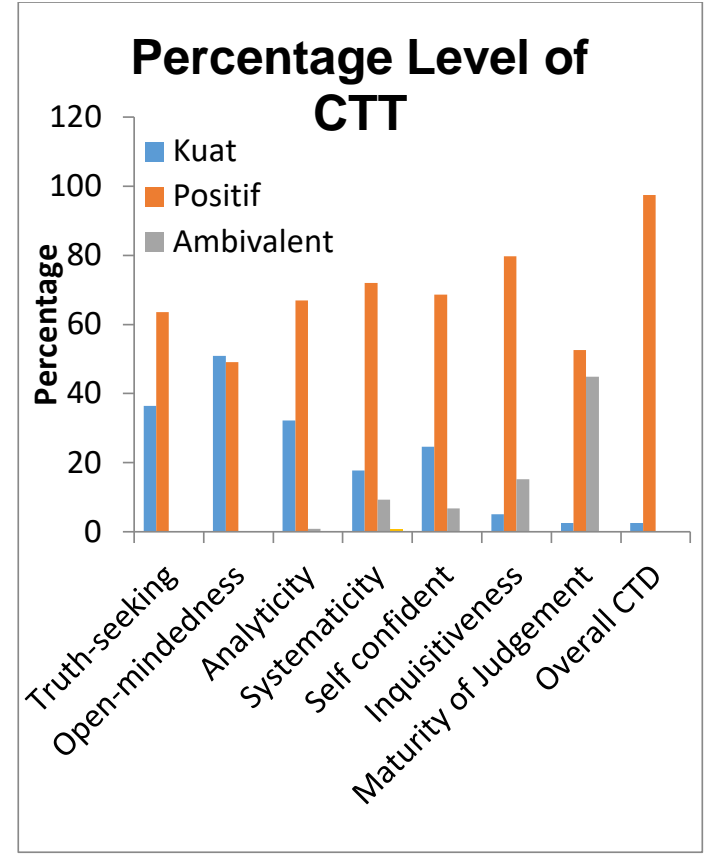

The results of the percentage analysis show that the level of critical thinking tendency of prospective primary school teachers is generally obtained by $2.54 \%$ in the strong category and $97.46 \%$ in the positive category.

The percentage of the level of categories for each indicator is for the Truth-seeking indicator as much as $36.44 \%$ in the strong category and $63.56 \%$ is in the positive category, and none is included in the ambivalent and negative categories. Likewise in the open mindedness and analytic indicators there are no ambivalent and negative categories, the CTT level in this indicator is only in strong and positive categories, respectively $49.15 \%$ and $58.85 \%$ for the Open mindedness indicator and $32.2 \%$ and $66.95 \%$ for the analyticity indicator. This means that the level of student inclination on the three indicators above is good.

The truth-seeking indicators are the implications of the developing reasoning ability. Enhancing the ability of logical inference and constructing concepts can be used by students to improve their ability to draw conclusions and the truth of a problem. The ability to find truth is enhanced through the learning process received by someone. Student learning process demands to validate the truth of a problem, so students are accustomed to thinking to find the truth when receiving a problem [16].

Meanwhile, the other four indicators are the students who have a tendency to ambivalent categories, even specifically for systematic indicator detected there are still in negative categories, even though the percentage is very small at $0.85 \%$. Of these four indicators, the indicator of maturity of judgment has the largest percentage of ambivalent categories compared to other indicators, which is $44.92 \%$. Nearly $50 \%$ of the sample has an ambivalent level of maturity of judgment. This means that students still need guidance and exercises to be able to improve their ability to make mature decisions.
The maturity is influenced by the culture or customs usually applied in certain place. Culture or customs in which people were not accustomed in asking questions, especially questions with critical thinking and a lack of broad perspective. This causes a lack of opportunities for someone to learn, a way of looking at things that have different views with him and when making decisions for a problem. This factor is one of the causes of the lack of maturity in making decisions owned by students [11].

The level of critical thinking tendencies of students is influenced by several factors including student motivation, student habits and learning experiences through [17]. The tendency to critical thinking is influenced by habits such as the number of hours a person reads, motivation and discipline of a person. Students who spend more time reading will have a higher tendency to think critically. Students have also been familiarized and given the opportunities to discuss, argue, and argue so that it increases the tendency to think openly in accepting an opinion or new knowledge. Prospective primary school teacher students are familiarized with a learning system that invites students to be open-minded about something, students are taught to have mutual opinions and respect for someone who voices their opinions.

People's academic achievement also influences their critical thinking tendencies. Someone who has high academic achievement will have a tendency to think critically higher as well. [11] Education, institutions, and other professional factors such as habits can influence the tendency to critical thinking. The level of education will influence the tendency to think of other factors such as analytical skills, self-confidence, the ability to think systematically and one's curiosity about something. Learning at the university teaches students to think systematically and analytically so that it helps develop students' critical thinking tendencies.

There is a significant influence of literacy ability with someone critical thinking tendencies [18]. The higher people literacy ability, the higher critical thinking tendency he/she has, and vice versa. The lower people literacy ability, the lower critical thinking tendency he/she has. Literacy ability is a prerequisite for critical thinking. The critical thinking tendency continuously happens with the grade level of a student. Learning at university has an enormous influence on the development of the ability to think critically [19]. However, several other studies show different results [14]. Differences in results may be obtained by researchers.

The critical thinking tendencies are related to various limitations, various methods and approaches in research, cultural differences and ways of learning of each person, and one's habits. Assessment of critical thinking tendencies requires further research related to the influence of each indicator of critical thinking tendencies that exist.

\section{CONCLUSION AND SUGGESTION}

\section{A. Conclusion}

The critical thinking tendency (CTT) for primary school teacher candidates is in the positive category, in which the most prominent CTT indicator shown by respondents is open mindedness, meanwhile the CTT 
indicator maturity of judgment (maturity in making decisions) is still categorized in ambivalent criteria.

\section{B. Suggestion}

Education from primary to tertiary level needs to orient students with questions and activities that are able to foster CTT habits and thinking skills. Thus, the knowledge acquired does not only stop at the conceptual order, and low-level thinking skills (LOTS), but it also is able to develop higher-order thinking skills (HOTS). In addition, this research needs to be developed more broadly for respondents who are more varied, ranging from basic education level to tertiary education.

\section{REFERENCES}

[1] Guerriero,S. 2014. Teacher's Pedagogical Knowledge and the Teaching Profession. Background Report and Project Objectives. diakses tanggal 5 september 2017.

[2] Supartini, 2003. Peran Guru dalam Pembaharuan Pendidikan. Artikel Dinamika Pendidikan No.1(x) diekses tanggal 5 september 2017.

[3] Ansari, S.U., dan Sufiana, K.,M. 2013. Image of an Effective Teacher in 21st Century Classroom. Journal of Educational And Instructional Studiesin The World. 3(4) Article: 08 ISSN: 21467463

[4] Johnson, C.M. (2000). Reconsidering the Ad Hominem, Philosophy, Vol. 84, 2009, pp. 251-266.

[5] Ennis, R. 2011. The Nature of Critical Thinking: An Outline of Critical Thinking Dispositions and Abilities. diakses pada $28 \mathrm{Mei}$ 2016 dari http://faculty.education.illinois.edu/rhennis/ documents/The Nature of Critical Thinking_51711_000.pdf

[6] Facione, A. 2011. Critical Thinking:What It Is and Why It Counts. Measured Reasons and The California Academic Press, Millbrae, CA. (http://www.insightassessment.com)
[7] Facione, P.A. 1990. Critical Thinking : A Statement of Expert Consensus for Purposes of Educational Assesment and Instruction. Executive Summary "The Delphi Report”. California Academi Press : Millbrae. Diakses 11 juli 2016.

[8] Norris, S.P. (1992). The Generalizability of Critical Thinking: Multiple Perspectives on Educational Ideal. New York: Teachers College.

[9] Facione, P.A. (2009). Critical Thinking : what It Is and Why I Counts.The California Academy Press.(http://www.insightassessment.com)

[10] Ennis, R.H. (1989). Critical thinking and subject specificity: clarification and needed research. Educational Researcher, 2(13): 13-16.

[11] Tiwari, A., Avery, A., \& Lai, P. (2003). Critical Thinking Disposition of Hong Kong Chinese and Australian Nursing Students. Journal of Advanced Nursing 44(3), 298-307.

[12] Ordem, E. (2017). Developing Critical-Thinking Dispositions in a Listening/Speaking Class . English Language Teaching Vol.10 No.1, 50-55.

[13] Yildirim, B., \& Ozkarahman, Ş. (2011). Examination of Critical Thinking Disposition in Nursing. International Journal of Humanities and Social Science Vol. 1 No.16, 173-182.

[14] Bilen, K., Ercan, O., \& Akcaozoglu, E. (2013). Identification of Critical Thinking Disposition of Teacher Candidates. Antropologist 16(3), 435-448.

[15] Turan, H., Kolayis, H., \& Ulusoy, Y. O. (2012). Comparison of the Faculty of Education Student's Critical Thinking DIsposition. Procedia - Social and Behavioral Sciences 46, 2020-2024.

[16] Gunawan, \& Liliasari. (2012). Model Virtual Laboratory Fisika Modern untuk Meningkatkan Disposisi Berpikir Kritis Calon Guru. Cakrawala Pendidikan, 185-199.

[17] Lai, E. R. (2011). Critical Thinking: A Literature Review. London: Pearson.

[18] Saglam, A. C., Cankaya, I., Ucer, H., \& Cetin, M. (2017). The Effect of Information Literacy on Teacher's critical Thinking Disposition. Journal of Education and Learning Vol.6 No.3, 31-40.

[19] Demirhan, E., \& Koklukaya, A. N. (2014). The Critical Thinking Dispositions of Preospective Science Teachers. Procedia -Social and Behavioral Sciences 116, 1551-1555. 